\title{
The burden of pneumococcal disease in the Canadian population before routine use of the seven-valent pneumococcal conjugate vaccine
}

\author{
Adrienne Morrow BSc${ }^{1}$, Philippe De Wals MD PhD ${ }^{1}$, Geneviève Petit MD MSc FRCPC ${ }^{2}$, \\ Maryse Guay MD MSc FRCPC ${ }^{3}$, Lonny James Erickson $\mathrm{PhD}^{4}$
}

A Morrow, P De Wals, G Petit, M Guay, LJ Erickson. The burden of pneumococcal disease in the Canadian population before routine use of the seven-valent pneumococcal conjugate vaccine. Can J Infect Dis Med Microbiol 2007;18(2):121-127.

BACKGROUND: In the United States, implementation of the sevenvalent conjugate vaccine into childhood immunization schedules has had an effect on the burden of pneumococcal disease in all ages of the population. To evaluate the impact in Canada, it is essential to have an estimate of the burden of pneumococcal disease before routine use of the vaccine.

METHODS: The incidence and costs of pneumococcal disease in the Canadian population in 2001 were estimated from various sources, including published studies, provincial databases and expert opinion. RESULTS: In 2001, there were 565,000 cases of pneumococcal disease in the Canadian population, with invasive infections representing $0.7 \%$, pneumonia $7.5 \%$ and acute otitis media $91.8 \%$ of cases. There were a total of 3000 deaths, mainly as a result of pneumonia and largely attributable to the population aged 65 years or older. There were 54,330 life-years lost due to pneumococcal disease, and 37,430 quality-adjusted life-years lost due to acute disease, long-term sequelae and deaths. Societal costs were estimated to be $\$ 193$ million (range $\$ 155$ to $\$ 295$ million), with $82 \%$ borne by the health system and $18 \%$ borne by families. Invasive pneumococcal infections represented $17 \%$ of the costs and noninvasive infections represented $83 \%$, with approximately one-half of this proportion attributable to acute otitis media and myringotomy.

CONCLUSIONS: The burden of pneumococcal disease before routine use of the pneumococcal conjugate vaccine was substantial in all age groups of the Canadian population. This estimate provides a baseline for further analysis of the direct and indirect impacts of the vaccine.

Key Words: Burden; Canada; Pneumococcal disease; Vaccine
Le fardeau de la maladie à pneumocoque au sein de la population canadienne avant l'utilisation systématique du vaccin conjugué heptavalent contre le pneumocoque

HISTORIQUE : Aux États-Unis, l'implantation du vaccin conjugué heptavalent dans les calendriers de vaccination pour enfants a eu un effet sur le fardeau de la maladie à pneumocoque au sein de la population de tout âge. Pour en évaluer les répercussions au Canada, il est essentiel d'estimer le fardeau de la maladie à pneumocoque avant l'utilisation systématique du vaccin.

MÉTHODOLOGIE : On a estimé l'incidence et le coût de la maladie à pneumocoque au sein de la population canadienne en 2001 auprès de diverses sources, y compris les études publiées, les bases de données provinciales et l'opinion d'experts.

RÉSULTATS : En 2001, on a recensé 565000 cas de maladie à pneumocoque au sein de la population canadienne, les infections envahissantes représentant 0,7 \% des cas, les pneumonies, 7,5\% et l'otite moyenne aiguë, 91,8 \%. Au total, 3000 personnes sont décédées, principalement en conséquence d'une pneumonie et dans la population de 65 ans et plus. On a répertorié 54330 années de vie perdues en raison de la maladie à pneumocoque, et 37430 années de vie pondérées par la qualité perdues en raison d'une maladie aiguë, de séquelles à long terme et des décès. On a évalué les coûts sociétaux à 193 millions de dollars (plage de 155 millions de dollars à 295 millions de dollars), 82 \% étant assumés par le système de santé et $18 \%$, par les familles. Les infections à pneumocoque envahissantes représentaient $17 \%$ des coûts, et les infections non envahissantes, $83 \%$ des coûts, environ la moitié de cette proportion étant attribuable à l'otite moyenne aiguë et à la paracentèse.

CONCLUSIONS : Le fardeau de la maladie à pneumocoque avant l'utilisation systématique du vaccin conjugué contre le pneumocoque était considérable dans tous les groupes d'âge de la population canadienne. La présente évaluation fournit des données de base pour procéder à une analyse plus approfondie des répercussions directes et indirectes du vaccin.

the vaccine into routine childhood immunization schedules in 2000 was followed by a marked decrease in the incidence of invasive pneumococcal disease in all ages of the population $(4,5)$. To evaluate the real direct and indirect impacts of PCV-7 in Canada, it is necessary to estimate the burden of pneumococcal disease for all ages before vaccine implementation.

${ }^{1}$ Department of Social and Preventive Medicine, Laval University, Quebec City; ${ }^{2}$ Department of Social and Preventive Medicine,

University of Montreal, Montreal; ${ }^{3}$ Department of Community Health Sciences, University of Sherbrooke, Sherbrooke; ${ }^{4}$ Quebec Agency for

Health Services and Technology Assessment, Montreal, Quebec

Correspondence and reprints: Dr Philippe De Wals, Department of Social and Preventive Medicine, Laval University, 2180, chemin Ste-Foy,

Quebec City, Quebec. Telephone 418-656-2131 ext 7374, fax 418-656-7759, e-mail Philippe.Dewals@msp.ulaval.ca

Received and accepted for publication July 26, 2006 
However, there exist few fragmented data on the burden of pneumococcal disease in the Canadian population. A study was conducted on children nine years of age or younger in 2000 (6), and on children 12 years of age or younger from 1994 to 1998 (7). The objective of the present study was to estimate the epidemiological and economic burden of pneumococcal disease for all ages of the Canadian population before the implementation of PCV-7 into vaccine programs.

\section{METHODS}

\section{Epidemiological parameters}

The analysis was based on the 2001 Canadian population estimates (8), before significant use of the vaccine. The major pneumococcalassociated illnesses were included in the analysis based on the availability of epidemiological vaccine effectiveness data $(9,10)$. Mutually exclusive outcomes, categorized hierarchically, included pneumococcal meningitis and pneumococcal bacteremia with or without pneumonia, pneumonia without bacteremia, acute otitis media (AOM) and myringotomy with ventilation tube insertion (MVT). Sinusitis was the only common pneumococcal manifestation not included in the analysis, because the incidence and proportion of infections caused by Streptococcus pneumoniae are unknown. Other manifestations (eg, bone and joint, and cardiovascular infections) are generally rare and thus were not included.

\section{Invasive disease}

For children younger than 16 years of age, the age-specific incidence of pneumococcal disease has been calculated by Petit et al (6). For those aged 16 years or older, the incidence of invasive pneumococcal disease was estimated from various sources. Population-based, age-specific invasive pneumococcal disease rates were available for the Calgary, Alberta, area for the years 1998 to 2001 (Jim Kellner, personal communication). The proportion of invasive pneumococcal disease diagnosed as meningitis and bacteremia was calculated using American data from the Active Bacterial Core Surveillance/Emerging Infections Program Network (11). This proportion was applied to the Calgary area data. The percentage of cases hospitalized for bacteremia among children 16 years of age or younger was estimated to be $62 \%$ by combining data from three different data sources: the Quebec Provincial Notifiable Diseases Database, the Quebec Provincial Reference Laboratory and the Immunization Monitoring Program ACTive (IMPACT) (6). For adults 18 years of age or older, the percentage hospitalized was determined to be $83.7 \%$ from a prospective study conducted in the Edmonton, Alberta, area (12).

\section{Pneumonia}

The incidence of all-cause hospitalized pneumonia cases was determined from the Quebec hospital administrative data system (Med-Echo) from the years 1991 to 2001 using ICD-9 codes 480.0 to 486.9 for the primary diagnosis. To determine the incidence of all-cause nonhospitalized pneumonia cases, the ratio of hospitalized to nonhospitalized pneumonia cases was determined from a population-based study conducted in Finland (13) and then applied to the Canadian data. The proportion of hospitalized pneumonia due to $S$ pneumoniae in children 16 years of age or younger has been estimated to be $22 \%$ by Petit et al (6). However, the proportion of pneumonia attributable to $S$ pneumoniae is an uncertain parameter. Therefore, a sensitivity analysis was conducted by varying these values between a lower value of $13 \%$ (14) and an upper value of $37 \%$ (15). For individuals 17 years of age or older, the fraction of hospitalized pneumonia due to $S$ pneumoniae was determined to be $17 \%$ based on a meta-analysis of 10 selected studies that defined the etiology of community-acquired pneumonia requiring hospitalization, and the $\mathrm{CI}$ of this estimate was used to define the lower (13\%) and upper (35\%) values (16).

\section{AOM and MVT}

The age-specific incidence for AOM and MVT from two months to nine years of age has been previously determined using data from Manitoba and Quebec (6). The percentage of AOM cases due to $S$ pneumoniae has been determined in a prospective study in Finland, in which pneumococcal etiology was identified in $30.8 \%$ of AOM cases (17). Because this is another uncertain parameter, a sensitivity analysis was conducted using a lower limit of $28 \%$ (18) and an upper limit of $35 \%$ $(19,20)$. The age-specific, global MVT incidence was determined using data from the Med-Echo system, as well as from expert consultation (6). The proportion of MVT procedures resulting from $S$ pneumoniae was estimated to be $50 \%$ by expert opinion (21). A range of 50\% was assumed due to the uncertainty of this parameter; thus, upper and lower limits of $75 \%$ and 25\% were used, respectively. AOM and MVT outcomes were not included for individuals older than nine years of age, because the disease is less common in school-aged children and adolescents, and is infrequent in adults (22).

\section{Mortality}

A case fatality rate for pneumococcal meningitis among children 17 years of age or younger was determined to be $6.5 \%$ from a survey conducted among 11 pediatric centres of IMPACT (jointly sponsored by the Canadian Paediatric Society and the Laboratory Centre for Disease Control), including academic centres located across Canada, and accounts for approximately $85 \%$ of the tertiary care pediatric beds in Canada (23). For adults 18 years of age or older, a case fatality rate of $27.6 \%$ was estimated by determining a weighted average from several studies (24-26). The case fatality rate for hospitalized pneumococcal bacteremia for children nine years of age or younger was estimated to be $2 \%$ from Canadian population-based surveillance data (23), and the case fatality rate for hospitalized pneumococcal pneumonia for the same age group was determined to be $1 \%$ from a population-based study conducted in Finland (13). For individuals 10 to 18 years of age, 18 to 64 years of age, and 65 years of age or older, the case fatality rates for pneumonia and bacteremia were $1.6 \%, 15 \%$ and $31 \%$, respectively, as determined by $S$ pneumoniae surveillance in the province of Quebec (27). It was assumed that there were no deaths due to nonhospitalized outcomes. The life expectancy of Canadians at different ages were used to calculate the life-year loss from pneumococcal disease-associated deaths (28).

\section{Morbidity}

A deafness rate of $13 \%$ resulting from meningitis for children 17 years of age or younger was determined from a meta-analysis of randomized clinical trials (29). For adults 18 years of age or older, a deafness rate of $26 \%$ was determined $(24,25)$. A neurological disability rate of $7 \%$ (30) was used for survivors of meningitis 17 years of age or younger, and $19 \%$ was used for adults 18 years of age or older $(24,25)$. The utility values for survivors of meningitis were also determined. Hearing loss was considered to be a mild disability state, valued at 0.8 , while neurological sequelae were considered to be severe, valued at 0.6 (a value of 0 corresponds to death and 1 to perfect health) (31). For acute disease, the coefficients used for quality-adjusted life-year loss were 0.0079 for 
hospitalized bacteremia, 0.0232 for meningitis, 0.004 for nonhospitalized pneumonia, 0.006 for hospitalized pneumonia and 0.005 for otitis media (32). The quality-adjusted life-year loss was then calculated based on the disability-free life expectancy of Canadians (33).

\section{Economic parameters}

Financial costs are expressed in Canadian dollars for the year 2001, and any prices used from before or after this year were adjusted using the Canadian price index for health and personal care (34).

Costs for hospitalization were calculated using the All Patient Refined Diagnosis Related Groups and Resource Intensity Weights classification systems in Quebec. Hospital records of patients with pneumococcal meningitis (ICD-9 code 320.1), pneumococcal bacteremia (ICD-9 code 038.2) and pneumococcal pneumonia (ICD-9 code 481.9) as a primary diagnosis were identified, and mean values of hospitalization costs were calculated. Physician fees were determined from the National Grouping System Categories Report, Canada, 2001-2002 (35). It was assumed that for each diagnostic category, the patient would have had both a consultation and a major assessment on the first day of hospitalization, and would have been seen once daily for the remainder of the hospital stay by either an internist or a pediatrician. For patients diagnosed with meningitis, a major assessment by a neurologist was also included. For all hospitalized cases, the cost of one outpatient visit to either a family practitioner or pediatrician was also included, as well as the cost of a follow-up visit to a neurologist for cases of meningitis. The median length of hospital stay for individuals 19 years of age or younger was determined to be 11.5 days for meningitis, and three days for bacteremia and pneumonia (36). For adults 20 years of age or older with pneumonia and bacteremia, the median length of stay was determined to be five days (37), and for meningitis, 11.5 days (38). The long-term specialized schooling and medical costs for disability and deafness caused by meningitis were also included. The cost of special education for a duration of 12 years for children with bilateral deafness $(\$ 10,000 /$ year) was estimated from data provided by the Ministry of Education in Quebec (39). It was estimated that one-half of deafness cases resulting from pneumococcal meningitis were bilateral (40). The cost of specialized schooling associated with neurological disability was estimated using data from a study on birth defects in the United States (US\$200,000/case) (41). These costs were included in the average unit health care cost of pneumococcal meningitis (39). For adults 20 years of age or older, only the associated long-term medical costs were included, and for those 65 years of age or older, the value was halved to account for survival.

The direct and indirect costs assumed by families for children hospitalized with pneumococcal disease have been estimated by Petit et al (6). In the present study, only the direct costs were included due to a lack of data concerning the indirect costs associated with pneumococcal disease in adults. Family costs for hospitalized bacteremia and pneumonia in individuals 65 years of age or older were estimated from a study conducted in Edmonton on the private costs incurred by patients hospitalized with communityacquired pneumonia (42).

The costs incurred by the health care system for children with nonhospitalized pneumococcal disease were estimated from the doctor and family phone survey conducted by Petit et al (6). For adults, the cost was estimated by determining the price of medications used to treat these diseases. The costs associated with MVT have been previously estimated by Petit et al (6).

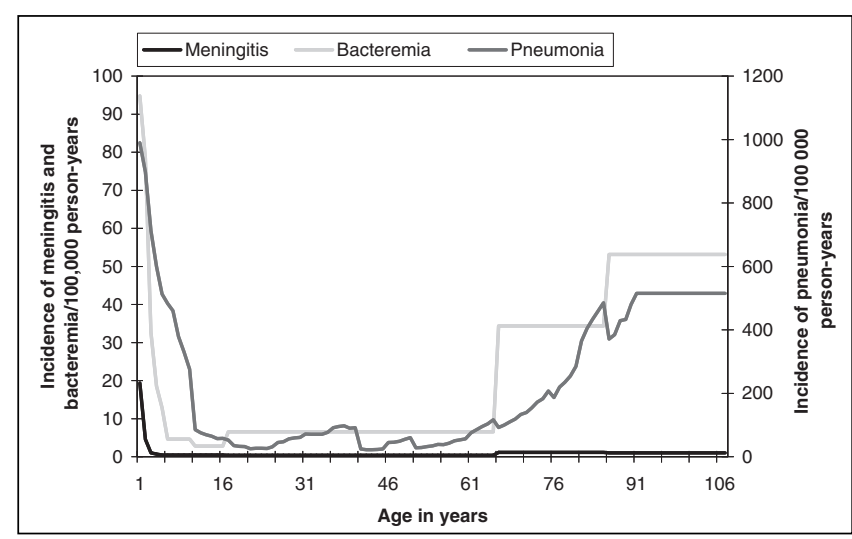

Figure 1) Age-specific incidence of pneumococcal meningitis, bacteremia and pneumonia in the Canadian population in 2001

\section{RESULTS}

The incidence of pneumococcal meningitis, bacteremia and pneumonia are presented in Figure 1. Disease incidence is high at a young age and then decreases significantly. Later in life (at approximately 65 years of age), the incidence begins to increase again, most dramatically for bacteremia and pneumonia. The estimated number of cases of pneumococcal-related outcomes in the Canadian population for the year 2001 are presented by age group in Table 1 . The large number of cases affecting children under one year of age demonstrates the high incidence at this young age. For all age groups, meningitis represents the smallest proportion of cases of pneumococcal disease, while AOM, although assumed to occur only until nine years of age, represents the largest proportion by far, with a total of 518,801 cases $(86 \%)$ (Table 1$)$.

Over a period of one year, a total of 38 deaths were attributed to meningitis, 545 deaths to bacteremia and 2419 to pneumonia. Deaths resulting from bacteremia and pneumonia were largely attributable to the population aged 65 years or older (data not presented in the tables). In addition, there were a total of 54,330 life-years lost due to pneumococcal disease (range 44,895 to 96,193), and 37,430 quality-adjusted life-years lost due to acute disease, long-term sequelae and deaths (range 31,102 to 62,510). The burden of disease expressed in quality-adjusted life-years is less than the burden expressed in life-years lost due to the decrease in average quality of life associated with aging.

The unitary costs to the health care system for pneumococcal disease are presented in Table 2 , and the unitary costs to families are presented in Table 3. The unitary cost of meningitis for the health care system is significant, because the costs of resulting sequelae are also included. The costs to families are highest for hospitalized outcomes, with meningitis being the most costly.

The total burden of pneumococcal disease in the Canadian population for 2001 by age category is presented in Table 4 . Although AOM has a relatively low family and health care system unit cost, due to the high number of cases, it represented a significant proportion of the burden until nine years of age. Among adults, hospitalized pneumococcal pneumonia carried the highest societal burden (Table 4). The overall societal costs of all cases of pneumococcal disease (including MVT) amounted to $\$ 193$ million, with $82 \%$ borne by the health care system and $18 \%$ borne by families (Table 4 ). Invasive pneumococcal infections had an overall disease cost of over $\$ 32$ million, which was $17 \%$ of the total costs. A very large proportion of this 
TABLE 1

Estimated number of cases of pneumococcal disease in the Canadian population in 2001

\begin{tabular}{|c|c|c|c|c|c|c|c|}
\hline & $\begin{array}{c}\text { Younger than } \\
\text { one year of age (n) }\end{array}$ & $\begin{array}{c}\text { One to four } \\
\text { years of age }(n)\end{array}$ & $\begin{array}{c}\text { Five to nine } \\
\text { years of age }(n)\end{array}$ & $\begin{array}{c}10 \text { to } 19 \text { years } \\
\text { of age }(n)\end{array}$ & $\begin{array}{c}20 \text { to } 64 \text { years } \\
\text { of age (n) }\end{array}$ & $\begin{array}{l}65 \text { years of age } \\
\text { or older }(n)\end{array}$ & Total $(\mathbf{n})$ \\
\hline Hospitalized meningitis & 64 & 24 & 9 & 17 & 67 & 45 & 226 \\
\hline Nonhospitalized bacteremia & 120 & 190 & 36 & 51 & 205 & 233 & 833 \\
\hline Hospitalized pneumonia & 819 & 1762 & 768 & 330 & 2679 & 6469 & 12,827 \\
\hline Nonhospitalized pneumonia & 2471 & 7896 & 6966 & 2026 & 7580 & 2509 & 29,449 \\
\hline Lower limit & 1460 & 4666 & 4116 & 1261 & 5796 & 1919 & 19,218 \\
\hline Upper limit & 4156 & 13,280 & 11,715 & 3545 & 15,605 & 5166 & 53,468 \\
\hline Acute otitis media & 120,643 & 253,353 & 144,805 & & & & 518,801 \\
\hline Lower limit & 109,676 & 230,321 & 131,641 & & & & 471,638 \\
\hline Upper limit & 143,008 & 304,667 & 177,661 & 4322 & 22,445 & 19,957 & 672,060 \\
\hline Myringotomy* & 804 & 17,691 & 16,400 & & & & 34,895 \\
\hline Lower limit & 402 & 8846 & 8200 & & & & 17,447 \\
\hline Upper limit & 1205 & 26,537 & 24,599 & & & & 52,342 \\
\hline
\end{tabular}

*Myringotomy is not included in total because it is a procedure associated with acute otitis media

TABLE 2

Unitary costs to the health care system for pneumococcal disease

\begin{tabular}{|c|c|c|c|c|c|c|}
\hline & $\begin{array}{l}\text { Younger than } \\
\text { one year of age }\end{array}$ & $\begin{array}{l}\text { One to four } \\
\text { years of age }\end{array}$ & $\begin{array}{l}\text { Five to nine } \\
\text { years of age }\end{array}$ & $\begin{array}{c}10 \text { to } 19 \\
\text { years of age }\end{array}$ & $\begin{array}{c}20 \text { to } 64 \\
\text { years of age }\end{array}$ & $\begin{array}{l}65 \text { years of } \\
\text { age or older }\end{array}$ \\
\hline Meningitis & $\$ 30,284$ & $\$ 30,996$ & $\$ 28,859$ & $\$ 28,859$ & $\$ 12,399$ & $\$ 9,891$ \\
\hline Hospitalized bacteremia & $\$ 7,337$ & $\$ 4,131$ & $\$ 4,488$ & $\$ 4,488$ & $\$ 10,233$ & $\$ 9,876$ \\
\hline Nonhospitalized bacteremia & $\$ 125$ & $\$ 125$ & $\$ 125$ & $\$ 125$ & $\$ 125$ & $\$ 125$ \\
\hline Hospitalized pneumonia & $\$ 1,994$ & $\$ 2,707$ & $\$ 3,775$ & $\$ 6,269$ & $\$ 6,671$ & $\$ 7,027$ \\
\hline Nonhospitalized pneumonia & $\$ 87$ & $\$ 87$ & $\$ 87$ & $\$ 87$ & $\$ 87$ & $\$ 87$ \\
\hline Acute otitis media & $\$ 60$ & $\$ 60$ & $\$ 60$ & & & \\
\hline Myringotomy & $\$ 539$ & $\$ 539$ & $\$ 539$ & & & \\
\hline
\end{tabular}

cost was borne by the health care system (96\%). Noninvasive infections amounted to more than $\$ 160$ million (83\% of total costs), with approximately $50 \%$ the costs due to AOM and MVT combined, and the other 50\% due to pneumonia. Of these costs, $79 \%$ was borne by the health care system.

\section{DISCUSSION}

The aim of the present study was to complete the data on the epidemiological and economic burden of pneumococcal disease in the Canadian population that have been determined for children nine years of age or younger (6), because few data exist for the adult population. In the study, all age groups were considered, so that the indirect effect of childhood vaccination with PCV-7 on the adult population could then be assessed. The outcomes evaluated in the study were restricted to those used in the childhood analysis (pneumococcal meningitis, bacteremia, pneumonia and otitis) (6). However, in contrast to the childhood analysis, the long-term costs associated with health care and specialized schooling for neurological disability and hearing loss resulting from meningitis were included, while indirect costs, such as productivity losses due to pneumococcal disease, were not. As in the previous study, there were no cost values assigned for the resulting pain, sorrow, anxiety and interpersonal tensions caused by pneumococcal disease (6).

The incidence rates of pneumococcal infections estimated in the present study are comparable with those observed in a cohort model study that evaluated the prevaccination pneumococcal epidemiology in England and Wales (43). Meningitis, bacteremia, pneumonia and otitis media were also used as outcomes in that study. However, the percentage of pneumonia and otitis cases attributed to $S$ pneumoniae, a factor that heavily influences the determination of disease incidence, differed slightly between the two studies. The English study estimated the proportion of pneumonia cases caused by $S$ pneumoniae to be $26 \%$ for all age groups, while the present study used more conservative values $(22 \%$ for individuals 17 years of age or younger [6] and $17 \%$ for those 18 years of age or older in the baseline analysis [16]). In contrast, the proportion of AOM due to S pneumoniae was estimated to be $23 \%$ by the English study, 
TABLE 3

Unitary costs to families for pneumococcal disease

\begin{tabular}{|c|c|c|c|c|c|c|}
\hline & $\begin{array}{l}\text { Younger than } \\
\text { one year of age }\end{array}$ & $\begin{array}{l}\text { One to four } \\
\text { years of age }\end{array}$ & $\begin{array}{l}\text { Five to nine } \\
\text { years of age }\end{array}$ & $\begin{array}{c}10 \text { to } 19 \\
\text { years of age }\end{array}$ & $\begin{array}{c}20 \text { to } 64 \\
\text { years of age }\end{array}$ & $\begin{array}{l}65 \text { years of } \\
\text { age or older }\end{array}$ \\
\hline Meningitis & $\$ 797$ & $\$ 797$ & $\$ 797$ & $\$ 797$ & $\$ 797$ & $\$ 797$ \\
\hline Hospitalized bacteremia & $\$ 266$ & $\$ 266$ & $\$ 266$ & $\$ 266$ & $\$ 266$ & $\$ 603$ \\
\hline Nonhospitalized bacteremia & $\$ 77$ & $\$ 77$ & $\$ 77$ & $\$ 77$ & $\$ 119$ & $\$ 119$ \\
\hline Hospitalized pneumonia & $\$ 266$ & $\$ 266$ & $\$ 266$ & $\$ 266$ & $\$ 266$ & $\$ 603$ \\
\hline Nonhospitalized pneumonia & $\$ 77$ & $\$ 77$ & $\$ 77$ & $\$ 77$ & $\$ 119$ & $\$ 119$ \\
\hline Acute otitis media & $\$ 45$ & $\$ 45$ & $\$ 45$ & & & \\
\hline Myringotomy & $\$ 45$ & $\$ 45$ & $\$ 45$ & & & \\
\hline
\end{tabular}

TABLE 4

Total burden of pneumococcal disease in the 2001 Canadian population by age group and fraction borne by the health system

\begin{tabular}{|c|c|c|c|c|c|c|c|c|}
\hline & $\begin{array}{l}\text { Younger than } \\
\text { one year of age }\end{array}$ & $\begin{array}{l}\text { One to four } \\
\text { years of age }\end{array}$ & $\begin{array}{l}\text { Five to nine } \\
\text { years of age }\end{array}$ & $\begin{array}{c}10 \text { to } 19 \\
\text { years of age }\end{array}$ & $\begin{array}{c}20 \text { to } 64 \\
\text { years of age }\end{array}$ & $\begin{array}{c}65 \text { years } \\
\text { of age or older }\end{array}$ & Total & $\begin{array}{c}\text { Borne by } \\
\text { health system }\end{array}$ \\
\hline Hospitalized meningitis & $\$ 2,001,000$ & $\$ 752,000$ & $\$ 275,000$ & $\$ 517,000$ & $\$ 883,000$ & $\$ 477,000$ & $\$ 4,905,000$ & $96 \%$ \\
\hline Hospitalized bacteremia & $\$ 1,485,000$ & $\$ 1,361,000$ & $\$ 276,000$ & $\$ 622,000$ & $\$ 11,042,000$ & $\$ 12,521,000$ & $\$ 27,307,000$ & $96 \%$ \\
\hline $\begin{array}{c}\text { Nonhospitalized } \\
\text { bacteremia }\end{array}$ & $\$ 24,000$ & $\$ 38,000$ & $\$ 7,000$ & $\$ 10,000$ & $\$ 50,000$ & $\$ 57,000$ & $\$ 186,000$ & $56 \%$ \\
\hline Hospitalized pneumonia & $\$ 1,850,000$ & $\$ 5,236,000$ & $\$ 3,104,000$ & $\$ 2,155,000$ & $\$ 18,584,000$ & $\$ 49,355,000$ & $\$ 80,284,000$ & $93 \%$ \\
\hline Lower limit & $\$ 1,093,000$ & $\$ 3,094,000$ & $\$ 1,834,000$ & $\$ 1,341,000$ & $\$ 14,212,000$ & $\$ 37,742,000$ & $\$ 59,316,000$ & $93 \%$ \\
\hline Upper limit & $\$ 3,112,000$ & $\$ 8,805,000$ & $\$ 5,220,000$ & $\$ 3,771,000$ & $\$ 38,262,000$ & $\$ 101,613,000$ & $\$ 160,783,000$ & $93 \%$ \\
\hline $\begin{array}{c}\text { Nonhospitalized } \\
\text { pneumonia }\end{array}$ & $\$ 405,000$ & $\$ 1,293,000$ & $\$ 1,141,000$ & $\$ 332,000$ & $\$ 1,562,000$ & $\$ 517,000$ & $\$ 5,250,000$ & $49 \%$ \\
\hline Lower limit & $\$ 239,000$ & $\$ 765,000$ & $\$ 674,000$ & $\$ 207,000$ & $\$ 1,194,000$ & $\$ 395,000$ & $\$ 3,474,000$ & $48 \%$ \\
\hline Upper limit & $\$ 681,000$ & $\$ 2,175,000$ & $\$ 1,919,000$ & $\$ 581,000$ & $\$ 3,215,000$ & $\$ 1,064,000$ & $\$ 9,635,000$ & $48 \%$ \\
\hline Acute otitis media & $\$ 12,709,000$ & $\$ 26,690,000$ & $\$ 15,255,000$ & & & & $\$ 54,654,000$ & $57 \%$ \\
\hline Lower limit & $\$ 11,554,000$ & $\$ 24,264,000$ & $\$ 13,868,000$ & & & & $\$ 49,686,000$ & $44 \%$ \\
\hline Upper limit & $\$ 14,443,000$ & $\$ 30,330,000$ & $\$ 17,335,000$ & & & & $\$ 62,108,000$ & $57 \%$ \\
\hline Myringotomy & $\$ 469,000$ & $\$ 10,329,000$ & $\$ 9,575,000$ & & & & $\$ 20,373,000$ & $92 \%$ \\
\hline Lower limit & $\$ 235,000$ & $\$ 5,165,000$ & $\$ 4,787,000$ & & & & $\$ 10,187,000$ & $92 \%$ \\
\hline Upper limit & $\$ 704,000$ & $\$ 15,494,000$ & $\$ 14,362,000$ & & & & $\$ 30,560,000$ & $92 \%$ \\
\hline Total & $\$ 18,943,000$ & $\$ 45,699,000$ & $\$ 29,633,000$ & $\$ 3,636,000$ & $\$ 32,121,000$ & $\$ 62,927,000$ & $\$ 192,959,000$ & $82 \%$ \\
\hline Lower limit & $\$ 16,631,000$ & $\$ 35,438,000$ & $\$ 21,722,000$ & $\$ 2,697,000$ & $\$ 27,381,000$ & $\$ 51,193,000$ & $\$ 155,062,000$ & $77 \%$ \\
\hline Upper limit & $\$ 22,449,000$ & $\$ 58,955,000$ & $\$ 39,395,000$ & $\$ 5,501,000$ & $\$ 53,452,000$ & $\$ 115,733,000$ & $\$ 295,485,000$ & $84 \%$ \\
\hline
\end{tabular}

Costs rounded off to the closest thousandth dollar

while a more significant proportion (31\% [17]) was attributed to AOM in the present study.

Surveillance by the American Active Bacterial Core Surveillance/Emerging Infections Program Network also determined the prevaccination incidence of invasive pneumococcal infections (11). There was substantial racial disparity in the disease incidence between the AfricanAmerican and non-African-American populations in all age groups (the incidence of invasive disease was approximately 2.5 times greater in the African-American population). However, when the incidence of the non-African-American population was compared with the incidence of the Canadian population determined in this study, the incidence rates were more comparable (the Canadian incidence rates were only slightly lower). The difference may be due to intercountry variations in diagnostic and surveillance practices. In addition, comparable disease incidence rates between countries are not necessarily an indicator that variations do not exist; thus, interstudy comparisons must be regarded cautiously.
The present study attempted to include all relevant and important parameters of the burden of pneumococcal disease in the Canadian population before the routine use of PCV-7. Many of the data are of Canadian origin, thus providing a better estimate of the burden of pneumococcal disease in this population. Although Canadian data were favoured over other sources, some American and Finnish data were used when this was not practical or possible. The limitations of the American data are described above. Furthermore, although not ideal, the Finnish data are most likely very applicable to the Canadian population, because the pneumococcal epidemiology and socioeconomic situation of the two countries are similar. A better integration of Canadian laboratory and administrative databases would assist in determining data specific to this country. There are certain limitations in the methodology of the analysis. Some of the values used were estimates made by experts when necessary data were not available, and the indirect costs, such as productivity losses resulting from disease, were also not included. However, the study covered all ages in the population, and the incidence of disease was mainly 
concentrated at the extremes of the age spectrum (infancy and advanced age). Therefore, individuals who are generally not employed and thus have minimal productivity losses represent the largest proportion of cases. In addition, some economic analysts have argued that productivity losses should not be included, because this may lead to double counting if quality-adjusted life-years lost are expressed (44). The exclusion of deaths from nonhospitalized outcomes due to a lack of data is another study limitation. S pneumoniae is certainly a significant source of fatal pneumonia cases among elderly people dying at home or in long-term care facilities; thus, mortality has most likely been underestimated in this age group.

\section{CONCLUSIONS}

The burden of pneumococcal infections in the Canadian population before routine use of PCV-7 was substantial for both families and the health care system. Determining this prevaccinal measurement of pneumococcal disease burden thus provides a baseline for future analyses concerning the effects of childhood PCV-7 use on the entire Canadian population.

ACKNOWLEDGEMENTS: This study was funded by the Quebec Ministry of Health, and was conducted jointly by Laval University, the Quebec National Public Health Institute and the Laval University Research Centre. Epidemiological data were kindly provided by Louise Jetté, Quebec Public Health Laboratory, Quebec National Health Institute, Quebec; Jim Kellner, Department of Pediatrics, and Department of Microbiology and Infectious Diseases, University of Calgary, Calgary, Alberta; Manale Ouakki, Public Health Research Unit, Quebec University Hospital Research Centre, Montreal, Quebec; and Guy Huard, Health and Social Services Development Agency of the National Capital, Quebec City, Quebec

\section{REFERENCES}

1. An Advisory Committee Statement (ACS). National Advisory Committee on Immunization (NACI). Statement on recommended use of pneumococcal conjugate vaccine. Can Commun Dis Rep 2002;28(ACS-2):1-32

2. Kellner JD, Church DL, MacDonald J, Tyrrell GJ, Scheifele D. Progress in the prevention of pneumococcal infection. CMAJ 2005;173:1149-51. (Erratum in 2006;174:67).

3. Public Health Agency of Canada. Publicly Funded Immunization Programs in Canada - Routine Schedule for Infants and Children. <www.phac-aspc.gc.ca/im/ptimprog-progimpt/table-1_e.html/2005>. (Version current at September 11, 2006).

4. Whitney CG, Farley MM, Hadler J, et al; Active Bacterial Core Surveillance of the Emerging Infections Program Network. Decline in invasive pneumococcal disease after the introduction of protein-polysaccharide conjugate vaccine. $\mathrm{N}$ Engl J Med 2003;348:1737-46.

5. McBean AM, Park YT, Caldwell D, Yu X. Declining invasive pneumococcal disease in the U.S. elderly. Vaccine 2005;23:5641-5.

6. Petit G, De Wals P, Law B, et al. Epidemiological and economic burden of pneumococcal diseases in Canadian children. Can J Infect Dis 2003;14:215-20.

7. Bjornson GL, Scheifele DW, Halperin SA. Population-based epidemiology of invasive pneumococcal infection in children in nine urban centers in Canada, 1994 through 1998. Pediatr Infect Dis J 2002;21:947-50.

8. Statistics Canada. Estimates of population, by age group and sex, Canada, provinces and territories, annual.

$<$ http://www40.statcan.ca/L01/cst01/demo31a.htm> (Version current at January 25, 2007)

9. Black S. Efficacy, safety and immunogenicity of heptavalent pneumococcal conjugate vaccine in children. Pediatr Infect Dis J 2000;19:187-95.

10. Black SB, Shinefield HR, Hansen J, Elvin L, Laufer D, Malinoski F. Postlicensure evaluation of the effectiveness of seven valent pneumococcal conjugate vaccine. Pediatr Infect Dis J 2001;20:1105-7.

11. Robinson KA, Baughman W, Rothrock G, et al; Active Bacterial Core Surveillance (ABCs)/Emerging Infections Program Network. Epidemiology of invasive Streptococcus pneumoniae infections in the United States, 1995-1998: Opportunities for prevention in the conjugate vaccine era. JAMA 2001;285:1729-35.

12. Shariatzadeh MR, Huang JQ, Tyrrell GJ, Johnson MM, Marrie TJ. Bacteremic pneumococcal pneumonia: A prospective study in Edmonton and neighboring municipalities. Medicine (Baltimore) 2005;84:147-61.

13. Jokinen $\mathrm{C}$, Heiskanen $\mathrm{L}$, Juvonen $\mathrm{H}$, et al. Incidence of communityacquired pneumonia in the population of four municipalities in eastern Finland. Am J Epidemiol 1993;137:977-88.

14. Gendrel D, Raymond J, Moulin F, et al. Etiology and response to antibiotic therapy of community-acquired pneumonia in French children. Eur J Clin Microbiol Infect Dis 1997;16:388-91.

15. Juven T, Mertsola J, Waris M, et al. Etiology of community-acquired pneumonia in 254 hospitalized children. Pediatr Infect Dis J 2000;19:293-8.

16. Mandell LA, Marrie TJ, Grossman RF, Chow AW, Hyland RH. Canadian guidelines for the initial management of communityacquired pneumonia: An evidence-based update by the Canadian Infectious Diseases Society and the Canadian Thoracic Society. The Canadian Community-Acquired Pneumonia Working Group. Clin Infect Dis 2000;31:383-421.

17. Eskola J, Kilpi T, Palmu A, et al; Finnish Otitis Media Study Group. Efficacy of a pneumococcal conjugate vaccine against acute otitis media. N Engl J Med 2001;344:403-9.

18. Heiskanen-Kosma T, Korppi M, Jokinen C, et al. Etiology of childhood pneumonia: Aerologic results of a prospective, populationbased study. Pediatr Infect Dis J 1998;17:986-91.

19. Bluestone CD, Stephenson JS, Martin LM. Ten-year review of otitis media pathogens. Pediatr Infect Dis J 1992;11(Suppl 8):S7-11.

20. Block SL. Causative pathogens, antibiotic resistance and therapeutic considerations in acute otitis media. Pediatr Infect Dis J 1997;16:449-56.

21. Lieu TA, et al. Projected cost-effectiveness of pneumococcal conjugate vaccination of healthy infants and young children. JAMA 2000;283:1460-8.

22. Klein JO. Otitis externa, otitis media, and mastoiditis. In: Mandell GL, Bennett JB, Dolin RD, eds. Principles and Practice of Infectious Diseases. Philadelphia: Churchill Livingstone, 2000:669-75.

23. Scheifele D, Halperin S, Pelletier L, Talbot J. Invasive pneumococcal infections in Canadian children, 1991-1998: Implications for new vaccination strategies. Canadian Paediatric Society/Laboratory Centre for Disease Control Immunization Monitoring Program, Active (IMPACT). Clin Infect Dis. 2000;31:58-64. (Erratum in 2000;31:850).

24. Auburtin M, Porcher R, Bruneel F, et al. Pneumococcal meningitis in the intensive care unit: prognostic factors of clinical outcome in a series of 80 cases. Am J Respir Crit Care Med 2002;165:713-7.

25. Kastenbauer S, Pfister HW. Pneumococcal meningitis in adults: Spectrum of complications and prognostic factors in a series of 87 cases. Brain 2003;126:1015-25.

26. van de Beek D, de Gans J, Spanjaard L, Weisfelt M, Reitsma JB, Vermeulen M. Clinical features and prognostic factors in adults with bacterial meningitis. N Engl J Med 2004;351:1849-59. (Erratum in 2005;352:950).

27. Jette LP, Lamothe F. Surveillance of invasive Streptococcus pneumoniae infection in Quebec, Canada, from 1984 to 1986: Serotype distribution, antimicrobial susceptibility, and clinical characteristics. J Clin Microbiol 1989;27:1-5.

28. Statistics Canada. Deaths 2003. <www40.statcan.ca/L01/cst01/ demo07a.htm $>$ (Version current at January 25, 2007).

29. McIntyre PB, Berkey CS, King SM. Dexamethasone as adjunctive therapy in bacterial meningitis: A meta-analysis of randomized clinical trials since 1988. JAMA 1997;278:925-31.

30. Pomeroy SL, Holmes SJ, Dodge PR, Feigin RD. Seizures and other neurologic sequelae of bacterial meningitis in children. N Engl J Med 1990;323:1651-7.

31. Torrance G. Preferences for health states: A review of measurement methods. In: Sinclair J, ed. Clinical and Economic Evaluations of Perinatal Programs. Vail: Mead Johnson, 1982.

32. Melegaro A, Edmunds WJ. Cost-effectiveness analysis of pneumococcal conjugate vaccination in England and Wales. Vaccine 2004;22:4203-14. 
33. Statistics Canada. Disability-free life expectancy, by province and territory. <http://www40.statcan.ca/L01/cst01/health38.htm> (Version current at January 26, 2007).

34. Statistics Canada. Consumer price index, health and personal care, by province. <http://www40.statcan.ca/L01/cst01/econ161a.htm> (Version current at January 25, 2007).

35. National Grouping System Categories Report, Canada, 2001-2002, Ottawa: Canadian Institute for Health Information, 2004.

36. Petit $\mathrm{G}$. Le fardeau des maladies pneumococciques pédiatriques au Canada et l'impact potentiel du vaccin pneumococcique conjugué, in Département des Sciences de la santé communautaire. Sherbrooke: Université de Sherbrooke, 2001.

37. Ioachimescu OC, Ioachimescu AG, Iannini PB. Severity scoring in community-acquired pneumonia caused by Streptococcus pneumoniae: A 5-year experience. Int J Antimicrob Agents 2004;24:485-90.

38. Fiore AE, et al. Clinical outcomes of meningitis caused by Streptococcus pneumoniae in the era of antibiotic resistance. Clin Infect Dis 2000;30:71-7.
39. De Wals P. Benefits and Costs of Immunization of Infants with Pneumococcal Conjugate Vaccine in Canada. Sherbrooke: Clinical Research Centre, Sherbrooke University Hospital, 2001.

40. Dodge PR, Davis H, Feigin RD, et al. Prospective evaluation of hearing impairment as a sequela of acute bacterial meningitis. $\mathrm{N}$ Engl J Med 1984:311:869-74.

41. Waitzman NJ, Scheffler RM, Romano PS. The Cost of Birth Defects. Lanham: University Press of America Inc, 1996.

42. Jacobs P, Marrie TH, Calder P. Private costs of patients hospitalized with community-acquired pneumonia. Can Respir ] 2005; 12:205-8.

43. Melegaro A, Edmunds WJ, Pebody R, Miller E, George R. The current burden of pneumococcal disease in England and Wales. J Infect 2006;52:37-48.

44. Beutels P. Potential conflicts of interest in vaccine economics research: A commentary with a case study of pneumococcal conjugate vaccination. Vaccine 2004;22:3312-22. 


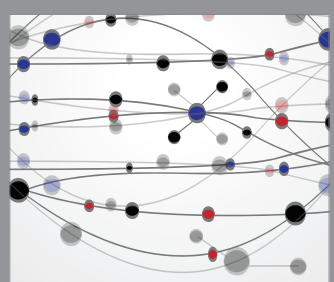

The Scientific World Journal
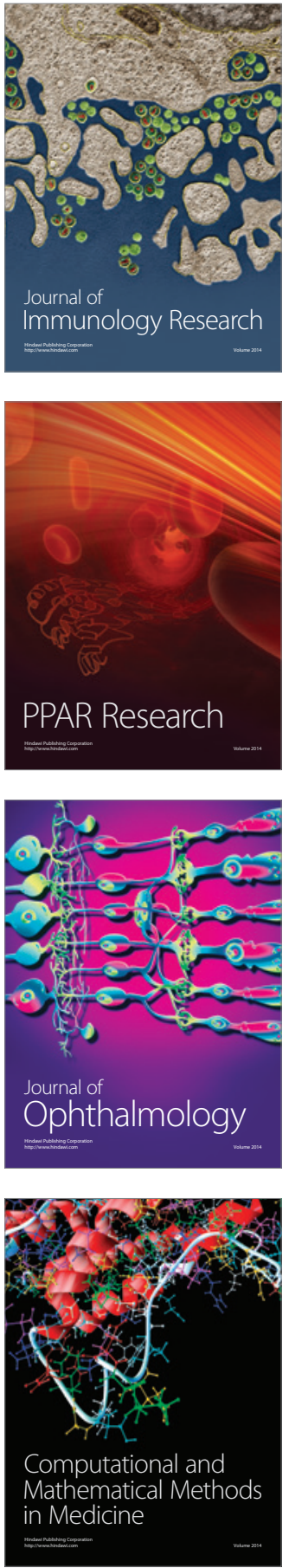

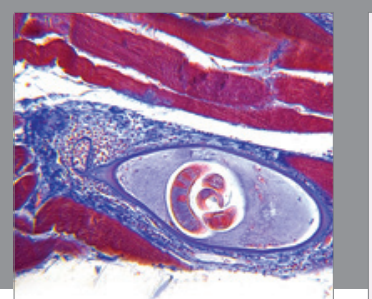

Gastroenterology Research and Practice

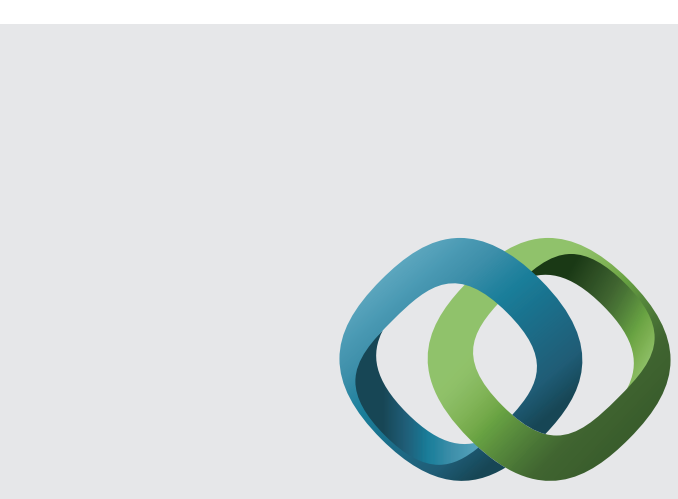

\section{Hindawi}

Submit your manuscripts at

http://www.hindawi.com
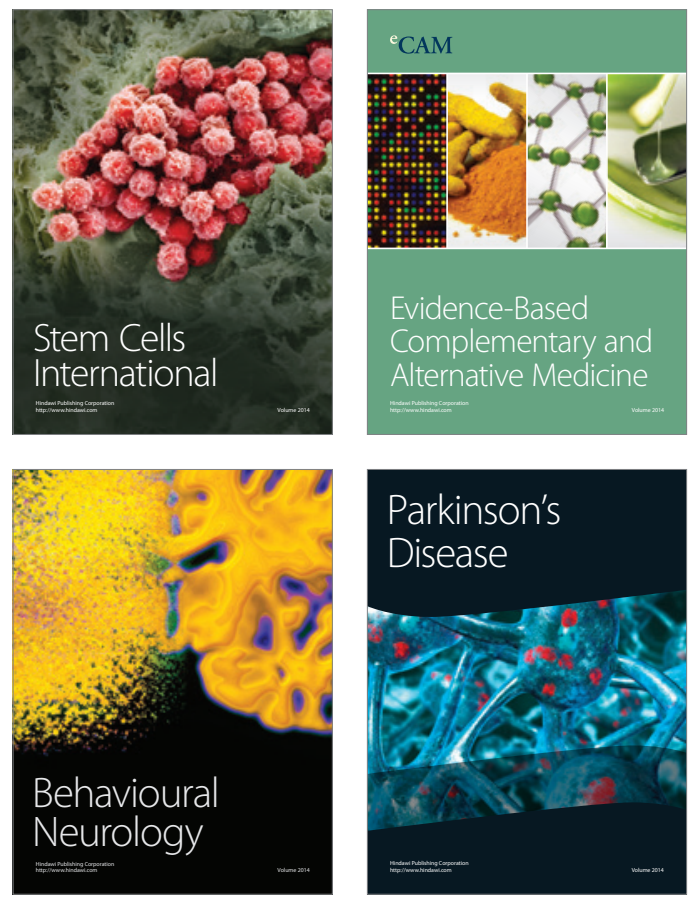
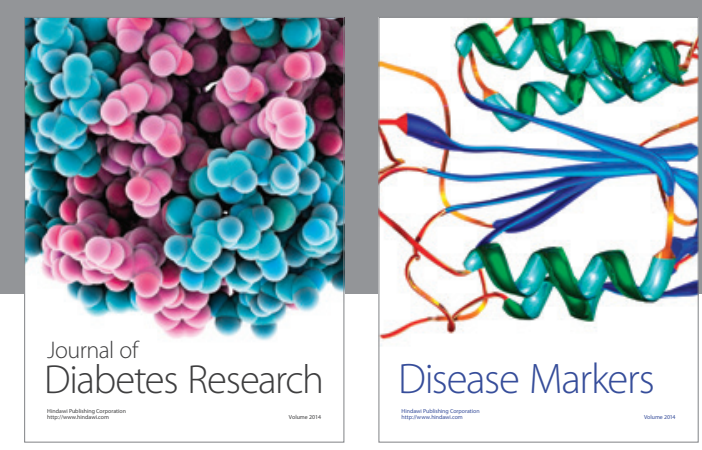

Disease Markers
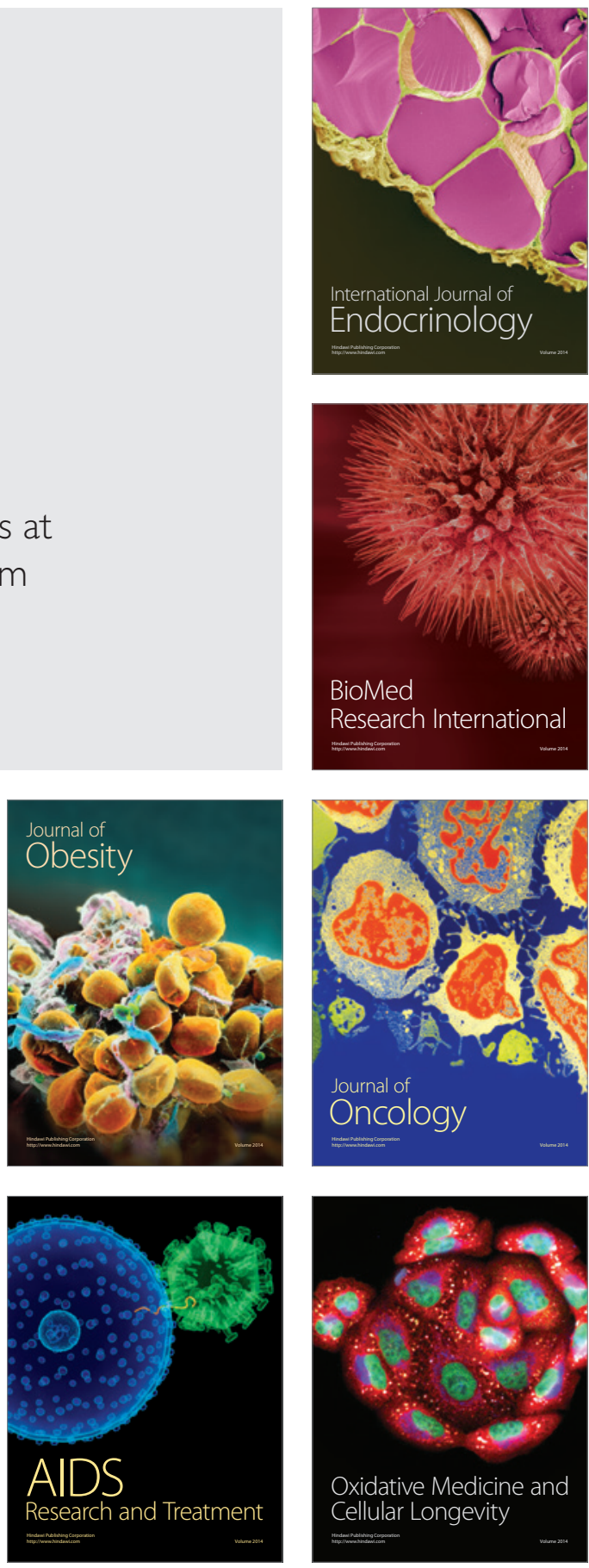